\title{
THE INDIGENOUS PERFORMING ARTS IN A SUMATRAN PROVINCE: REVIVAL OF SAKURA MASK THEATER, 1990-2012
}

\section{Karen Kartomi Thomas}

\section{Introduction}

Due to a vast transmigration program instituted by the Dutch from 1905 and persisting under the Indonesian government from the 1950s to the present, the ulun Lampung (indigenous Lampung people), comprising just 13 percent of the total population of Lampung province in Sumatra, have for decades remained a forgotten and neglected minority in their own province. The indigenous Lampung performing arts illuminate this social problem as demonstrated by the topic of this article-sakura masked theater performed by the Saibatin ethnic group living in Lampung's mountainous northwest. Unlike the performing arts in Java and other parts of Indonesia, which were largely regulated by the national arts' policies of Depdikbud (Departemen Pendidikan dan Kebudayaan, Ministry of Education and Culture) out of the national capital, Jakarta, the history of sakura masking has been determined by the marginalization of the ulun Lampung via the century-old transmigration program; this has resulted in their social stigmatization, perpetuated by communities of pendatang (newcomers). Reviving the arts was to take place through a program of promoting the Lampung philosophy of pi'il pesenggiri (self-respect) by drawing on components of traditional hospitality, including bestowing Lampung titles at traditional ceremonies on both guests visiting-and immigrants residing in-the province. This program was 
initiated by the current ulun Lampung governor not long after his appointment in 2003, and continues to be implemented today.

This article begins with a description of a sakura event, which took place in 2010 in Canggu village, West Lampung, and discusses its traditional meaning and social function. It then traces the history and changed function of sakura under the colonial through the national New Order and Reformasi governments to the present.

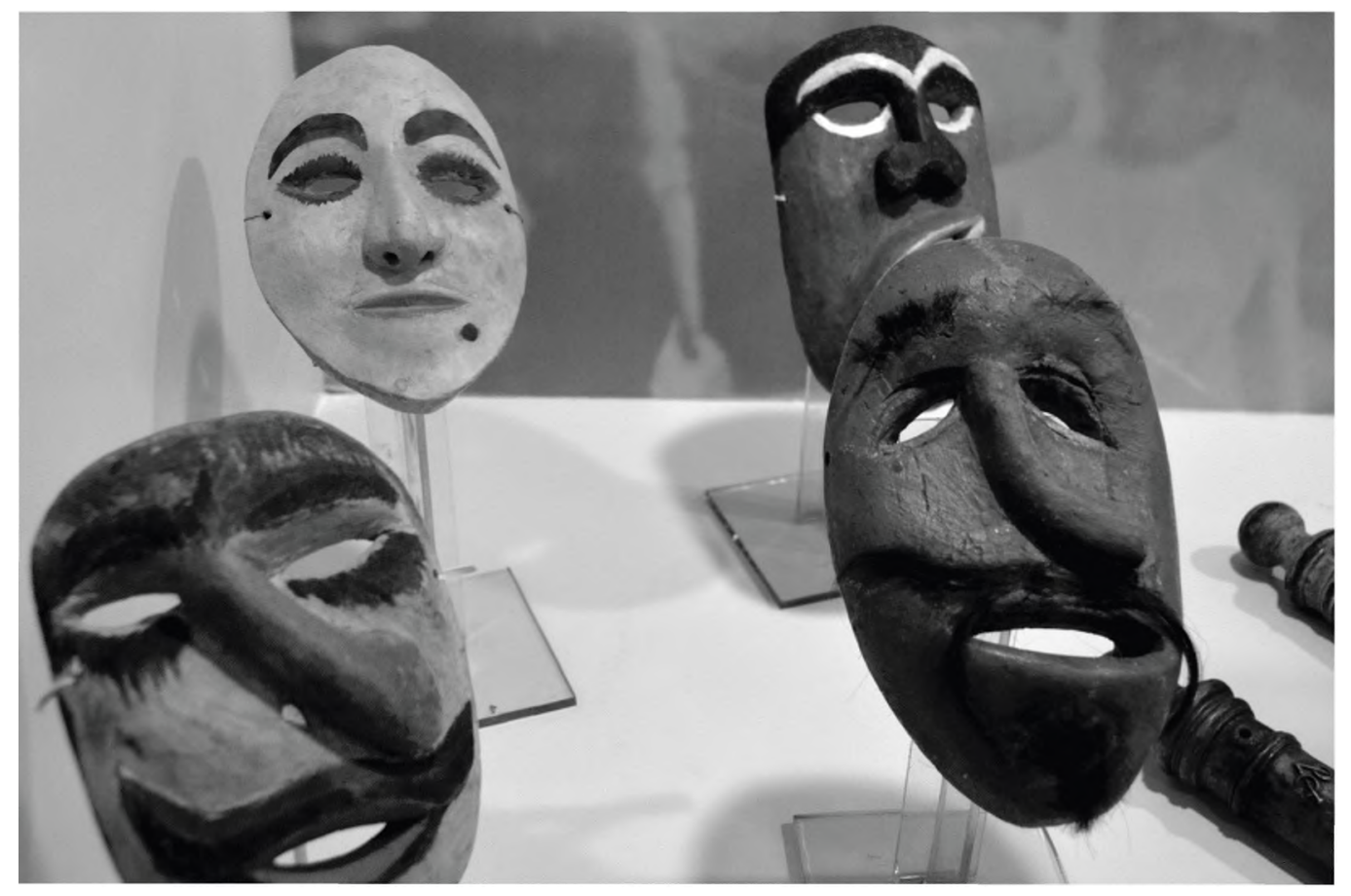

Figure 1. Lampung masks held in the State Museum of Lampung Province, "Ruwa Jurai," in the capital city of Bandar Lampung. Photograph: Karen Kartomi Thomas, 2012

\section{A Sakura Festival}

In August 2010, dozens of young men and boys gathered wearing roughly carved, wooden masks known as sakura kamak in the main street of the Skala Brak village of Canggu, located in the West Lampung regency (kabupaten), Sumatra.' The comic masks

\footnotetext{
${ }^{1}$ This sakura festival case study is based on information gathered from personal communications with artistic director Nyoman Mulyawan (a graduate from ISI [Institut Seni Indonesia] Jogjakarta) and many other performers; observations of a 2010 recording of the event that I could not attend; and also research on sakura found in a dissertation by Wayan Mustika. See Wayan Mustika, "Perkembangan Bentuk Pertunjukan Sakura Dalam Konteks Kehidupan Masyarakat Lampung Barat Tahun 1986-2009 [Developments in the Sakura Performance in Social Context in West Lampung, 1986-2009] (PhD dissertation, Sekolah Pascasarjana, Universitas Gadjah Mada, Jogjakarta, 2011). I am grateful to the many musicians, dancers, performers, officials, elders, and individuals in Lampung who generously provided me with their knowledge and information that is fundamental to this research. My research on the performing arts of Lampung, including masked theater, would not have been possible without the invitation, support, and generous assistance provided by the governor of Lampung, Drs Hi. Sjachroeddin. Finally, my sincere thanks go to the anonymous readers and SEAP editors Deborah Homsher and Fred Conner who provided valuable assistance during the writing and editing of various drafts of this article.
} 
depicted ugly and distorted human, animal, or ogre-like faces, including those of old men, kings, soldiers, warriors, monkeys, tigers, other animals, and clowns. The occasion was a village-cleansing (I. bersih desa ${ }^{2}$ ) procession carried out the week before Idul Fitri in preparation for the End-of-the-Fasting month. The faces of the symmetrical and asymmetrical masks brought to life demons and other spirits, and functioned to chase away evil beings believed to bring illness, disaster, and/or bad luck to the community. The costumes consisted of old clothes and leafy branches picked from coffee or palm trees. Processing together slowly as a group around the streets of the village in the first half of the event, sakura maskers sang bebandung ${ }^{3}$ verses and accompanied themselves by drumming loud interlocking rhythms (tetabuah terbangan) on a frame drum (I. rebana), ${ }^{4}$ periodically halting in front of homes and in the street to perform local style silat (I. martial arts) duels and comic skits to the delight of onlookers from Canggu and neighboring villages. In return for their entertainment, the maskers received contributions of food and drink from families who came out to watch and/or join the procession. Since it was held at the beginning of the Muslim month of Syawal, the event gave families the opportunity to carry out silaturahmi (I. come together in family and communal gathering) to nurture kinship ties, and forge strong family bonds (ajang ngejalang). ${ }^{5}$

Throughout the event, I observed that most of the hundreds of onlookers, including adults, adolescents, and children lining the main village street and watching from balconies in nearby homes, remained absorbed by the sights, sounds, and movements produced by the processing maskers. The initial speeches and formalities, and the drumming on the bedug (large drum), followed by music performed by the talo balak ensemble, ${ }^{6}$ alerted villagers to the imminent commencement of the festival. Once present, the audience tended to divide into groups of females and males, the females consisting of elders, mothers, young children, and adolescents, who stood or sat on the balconies and open stairwells of nearby homes and in groups around the stage space, and males consisting of elders, fathers, and adolescents, who stood together also in groups near the stage space. Not only did members of the audience move about spontaneously to make room for performers when requested (particularly as performers entered and exited the stage space), but their eyes and bodies, by my observation, remained intently focused on the action for the entire duration of the approximately four-hour performance. The color and movement of the procession merged smoothly with the pounding beats and rhythms of the rebana-playing and bebandung-singing performed by the maskers. After several hours of theater, dance, and continuous drumming, alternating also with music performed by musicians of the talo balak ensemble, the activity came to a standstill, and the music stopped momentarily. Members of the audience looked surprised, wondering what was to

\footnotetext{
${ }^{2}$ All foreign words are in Lampung language unless otherwise shown: I = Indonesian.

${ }^{3}$ Rhyming pantun verse sung in Lampung language.

${ }^{4}$ In some performances, musicians clap their hands or hit buckets to produce similar rhythms. I Wayan Mustika, "Perkembangan Bentuk Pertunjukan," p. 225.

${ }^{5}$ Ibid., p. 391.

${ }^{6}$ A talo balak ensemble consists of kelenongan (gong-chime), gong (hanging gong), bende (small gong), gujih (pair of cymbals), gendang (double-headed drum), bedug (large single-headed mosque drum), rebana (frame drum), gamolan pring (xylophone), seruling (flute). Mulyawan, personal communication with the author, April 2012, Kenali, West Lampung.
} 
come next. Only when the procession and the drumming started up again some moments later did the people appear to relax and reengage with the theater of masks once more. A little later a group of young children squealed and ran away in fear when the procession halted to make room for dancers with skull-like masks to perform large, sweeping leg and arm movements to the accompaniment of energetic drumming. The dimensions of the stage space waxed and waned as sections of the audience shifted about spontaneously. The ready smiles and laughter of those watching in response to the masks' comic faces and the actors' antics, and the almost immediate return of the young children, showed the allure of the spectacle and the audience's obvious captivation. $^{7}$

Legends passed down orally through the generations say that the ancestors of Lampung people were members of the animist Buay Tumi ethnic group, who, living in the old kingdom of Skala Brak, dating back to the thirteenth century $C E$, well before the arrival of Islam, most likely in the sixteenth century, donned wooden sakura masks in their rituals to chase away evil spirits. ${ }^{8}$ The ulun Lampung's belief that sakura was practiced among their pre-Muslim ancestors in Skala Brak gives sakura a legitimate connection to a powerful kingdom of the past. As an expression of the Saibatin ${ }^{9}$ identity of the West Lampung people, sakura is a tradition that has been performed for generations on and around the highest and most venerated peak, Mount Pesagi. ${ }^{10}$ It constitutes a unique way of affirming an indigenous profile and identity that is distinct from that of other ethnic groups.

Echoes of the masks' original purpose, i.e., to conceal the maskers' identities from lurking evil spirits, persists in the sakura kamak procession around the village today. While worn for their entertainment value, the ugly-looking masks are believed to have the power to evoke fear in undesirable supernatural beings, a quality that is reminiscent of the spiritual powers of the traditional shaman (I. bomoh). ${ }^{11}$ The sakura kamak maskers of Skala Brak, acting as intermediaries between humans and ancestral and nature spirits, were given the task of bringing forth the gods (I. para dewa) and the spirits of the ancestors (I. roh leluhur) from the upper- and underworld to protect villagers from sickness and the dangerous forces of nature (I. penguasa alam semesta). The earlier function of masks in West Lampung can be likened to those of some of the Dayak ethnic groups in Kalimantan, who believe that maskers are transformed into the spirits that the mask represents. ${ }^{12}$ Ceremonies were held to ensure that a balance

\footnotetext{
${ }^{7}$ The captivation refers to the affect of the combined theatrical elements in the moment of performance as its performative allure or its pesona (I.) See Karen Kartomi Thomas, "Enchanting the Audience: Dramatic Devices of Sakura Mask Theatre in West Lampung, Sumatra," Asian Theatre Journal 30,2 (2013): $390-414$.

${ }^{8}$ Mustika, "Perkembangan Bentuk Pertunjukan," p. 148-49.

${ }^{9}$ The ulun Lampung (Lampung people) divide into Saibatin and Pepadun groups. The Saibatin group comprises the Peminggir or coastal people, known as such since the Dutch colonial period. See Friedrich W. Funke, Orang Abung: Volkstrum Soed-Sumatras Im Wandel Vol 2: Das Leben in der Gegenwart [The Abung: The People of South Sumatra in Transition, vol. 2: Life in the Present] (Leiden: E. J. Brill, 1961). The Pepadun (also spelled Papadun and Papadon) groups living in the inland mountainous areas comprise the Abung and Pubian ethnic groups.

${ }^{10}$ Hasyimkan, personal communication, April 2012, Bandar Lampung; and Mustika, "Perkembangan Bentuk Pertunjukan," p. 10.

${ }^{11}$ Mustika, "Perkembangan Bentuk Pertunjukan,” p. 6.

${ }^{12}$ Michael Heppell, Masks of Kalimantan (Melbourne: Indonesian Arts Society, 1992), pp. 8, 24.

Asymmetrical faces of Dayak masks most likely represent beings from the underworld, whereas
} 
between nature and the spirits was maintained, and to drive out any evil spirits that might have descended on the community. It is likely that the people of Skala Brak also once wore sakura masks in shamanistic attempts to subdue malevolent ancestral spirits in trance, to celebrate fertility, and to give thanks for a successful harvest season. Charged with the job of protecting the village community and of bringing the people peace and harmony, sakura maskers were likely to have been viewed as embodiments of "potent" beings or ancestors who possess the power to fend off undesirable spirits that wreak havoc on human life. ${ }^{13}$

About halfway through the event, the procession stopped in the main street of the village, and fifteen masked dancers entered a demarcated area in the front yard of a home situated close to the street's edge. This time their masks were not made of wood, but of modern Lampung batik cloth that was wrapped tight around their heads and necks. These sakura helau ${ }^{14}$ masks resembled the shape of a helmet achieved by wrapping cloth tightly around a peci (I. Malay-shaped fez cap) resting on the top of the head, with the gaps between folds of cloth left open to expose the eyes, which were then covered with dark sunglasses. ${ }^{15}$ The performers wore teluk belanga (I. Malay-style trouser suits) with sarong, and two batik slendang (I. scarves) that lay diagonally across their chests. They carried long mock swords that gave them the appearance of kesatria (I. knight)-like heroes in battle. Unlike the sakura kamak maskers who moved about freely, processing slowly while playing the frame-drums and representing various comic human, animal, or demonic character-types, these sakura helau dancers performed energetic choreographed kreasi (I. newly created) dances in unison, with some of their stances and dance movements, to my mind, echoing those of the heroic male characters of both traditional Javanese wayang performances and traditional Balinese dance (discussed further below).

The choreographer of the sakura helau dances was the Balinese-born and Yogyakarta-trained artist I Wayan Mulyawan, a long-time resident of Liwa, the capital of West Lampung. After being recruited by the Dinas Pariwisata Seni dan Budaya Lampung Barat (West Lampung's Department of Tourism, Art, and Culture) in the early 1990s, he set up his own dance and music studio in Liwa known as Sanggar Seni Setiawan (Setiawan Arts' Studio) in order both to regenerate the West Lampung

symmetrical faces are likely to represent beings from the middle or human world. Similarly, the asymmetrical faces of sakura masks are likely to represent beings from the underworld or supernatural world.

${ }^{13}$ That Indonesians in general have a high regard for (and regularly pay their respects to) their deceased ancestors is examined in depth in Henri Chambert-Loir and Anthony Reid, "Introduction," in The Potent Dead: Ancestors, Saints, and Heroes in Contemporary Indonesia, ed. Henri Chambert-Loir and Anthony Reid (Sydney and Honolulu, HI: Allen \& Unwin and University of Hawaii Press, 2002), pp. xv-xvi.

${ }^{14}$ The word helau (L.) is translated as "clean" in the sense that the mask is made out of smooth materials, such as cloth, rather than roughly carved wood as in the kamak masks.

${ }^{15}$ The dark glasses (I. kacamata hitam) function as an adornment or accessory (I. semacam rias) and as an integral part of the costume. I was told that, like the wooden masks, they give some performers confidence when performing. (Performers from Sanggar Seni Setiawan [Seni Setiawan Studio], personal communication with the author, April 2012, Kenali, Lampung.) According to the sakura performers I spoke with in Kenali, the act of concealing their identities behind a mask allowed them to overcome any shyness, particularly if they had little or no experience in performing before an audience. As a form of mask, the dark glasses hide the eyes (I. fungsi penyembunyian), and they influence the facial expression and the physical appearance of the wearer (I. tampilan). See Suando, "Topeng" (unpublished manuscript, Jakarta, 2003), pp. 28-29. 
performing arts' traditions and to create Saibatin-inspired new dance forms (I. kreasi baru). ${ }^{16}$ As designated Head of Culture, his mandate from the West Lampung government was to revive the West Lampung performing arts, including sakura masked theater. This he did with members of the village community who studied dance, music, and performance under him. Young local males, many of whom have learned to play the frame-drum informally, having practiced since their early childhood, participate in sakura kamak processions after being invited to perform on celebratory occasions by local elders and officials organizing sakura. Sakura helau dancers are able to take part in sakura kamak processions as long as they know how to play the frame-drum; however, sakura kamak performers are unlikely to perform sakura helau dances unless they study the dances at a dance studio such as Mulyawan's first. Performers of sakura are selected from local rural village communities.

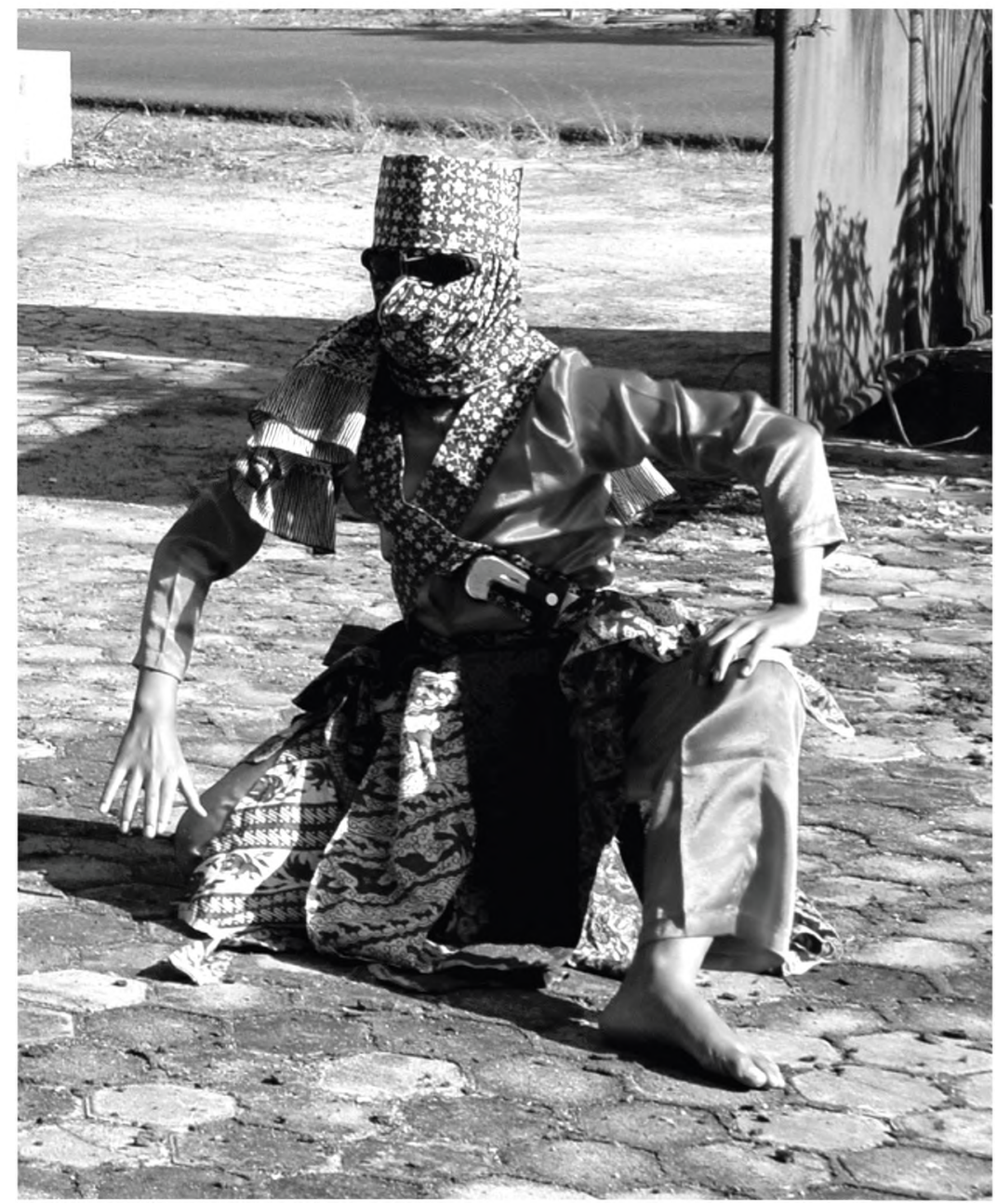

Figure 2. A male dancer from the Sanggar Seni Setiawan (Setiawan Arts Studio), wearing a Malay teluk belanga costume with a Lampung batik cloth mask and sunglasses, demonstrates a seated pose from the contemporary sakura helau dance in Liwa, West Lampung district. Photograph: Karen Kartomi Thomas, 2012

\footnotetext{
${ }^{16}$ Mulyawan, personal communication, April 2012, Kenali, Lampung.
} 
On the occasion of the sakura festival described here, at which government officials, artists, and members of the community converged, Mulyawan had requested permission from the camat (I. head of the district) in Canggu for members of his dance studio to perform a number of his original, sakura, and other kreasi dance routines. His contribution to the sakura festival at the annual village cleansing celebration related to Idul Fitri-the fact that he provided an afternoon of free entertainment-enabled him to give something back to members of a community who had welcomed him years ago when he arrived as a Balinese transmigrant (after having completed his performing arts training in Jogja). In his opening speech, Mulyawan publically expressed his gratitude to the cast and crew for their willingness to work together (beguai jejama) and with him to prepare, produce, and perform processional sakura masking and contemporary sakura dances as part of the Canggu sakura festival. The assistant bupati of West Lampung also spoke, offering congratulations to the artists and performers. Also in attendance was the president of the West Lampung branch of the Darma Wanita, who, with the assistant bupati, gave the closing remarks. While this was a village communal teater rakyat (I. people's theater) event, with the maskers acting in their bersih desa function, the officials' presence legitimized the event, which was filmed and kept as a historical record in the local government office in Liwa. ${ }^{17}$

From several conversations with young male and female artists in Kenali, it became clear to me that Mulyawan is well regarded by the community, in part due to his quiet, unassuming personality, but mainly due to his professional skills as an artist. ${ }^{18}$ Mulyawan gained local acceptance for his creative pieces well before the festival took place, as shown by the many dancers, musicians, stagehands, costume designers, and other assistants who agreed to offer their skills and services in his production, essentially without pay. Mulyawan's personable, understated manner as local "resident artist" enabled him to teach and run rehearsals through a hands-on, demonstrative approach, and to nurture his relationships with students as their teacher and cultural, artistic leader. The dancers, musicians, and other contributors saw their involvement in his production as an honor and as an act of assisting the official in charge to develop the West Lampung performing arts. ${ }^{19}$ Mulyawan had not only worked hard at creating a new version of sakura, as the bupati had asked him to do, but he had also worked hard at assimilating himself into the community. As the Head of Culture, who had settled in the Liwa area in the early 1990s, he oversaw-and continues to oversee-the conduct of the arts. Having worked in the community for more than two decades as an employee of the West Lampung government, and having been immersed in the study of Skala Brak's local cultural and artistic traditions, he and his family have been accepted into the local community. During this extended period of studying West Lampung music, dance, and theater from local village elders and indigenous artists, Mulyawan both choreographed new dances and taught the indigenous arts to local students. He spoke to me about the pride he felt for having developed new Lampung-inspired dance styles, including the version of sakura helau that has been officially endorsed and is performed alongside the traditional sakura kamak masked procession. Mulyawan represented government authority, but his

\footnotetext{
${ }^{17}$ Ibid

${ }^{18}$ Members of the Sanggar Setiawan Seni, personal communication, April 2012, Kenali, Lampung.

${ }^{19}$ Ibid.
} 
artistic standing among members of the community and his diplomatic function as gobetween among officials, artists, and the community facilitated unhampered the even artistic development in the province, and public acceptance of his new version of sakura helau masked dance.

Historically, performance genres in Lampung have long been subjected to degrees of official intervention, as in other regions of Indonesia (see next section). Mulyawan's careful approach in collaborating artistically both with local artists and communities, however, and his ability to negotiate successfully with the stakeholders involved-the performing arts community, the population of Skala Brak villages, and local government-was critical to the acceptance of his new sakura choreography. ${ }^{20}$

\section{The Performing Arts, Regional Autonomy, and Marginalization: The New Order through the Reformasi Era}

Tight controls administered by the New Order government from the nation's capital over the management of the arts and cultural policy have been widely documented. ${ }^{21}$ In the early 1970s, a vast project of "cultural engineering" commenced with a focus on the arts. ${ }^{22}$ The New Order government took systematic note of regional culture when the second Five-Year Development Plan went into effect in $1974 . .^{23}$ The activities of Depdikbud in the regional arts across the nation, from the provincial level to the village level, included ...

... registering performers, inventorying genres, supporting a small number of high school or college-level conservations and music academies, monitoring content, suggesting technical or stylistic changes in performance, selecting individuals and groups for financial assistance, producing festivals and competitions, commissioning performances for visiting dignitaries and state occasions, subsidizing appearances on local television, and even arranging travel to Jakarta to perform at the national theme park, Taman Mini. ${ }^{24}$

During this period, the Depdikbud regulated the political and moral content of performances across Indonesia's regions. Performers seemed willing to follow Depdikbud's suggestion of "upgrading" their forms and therefore aligning the content and delivery of their traditional arts with the official line. Those who subordinated the local aesthetic to fulfill Depdikbud's expectations had greater hopes of receiving

\footnotetext{
${ }^{20}$ This artistic development of sakura, influenced by Depdikbud's intervention, differs markedly from tayuban performance in Blora (Central Java) of the 1990s, for example. In Blora, the participants resented official intervention and "felt defeated by the dances of the officials who received instruction in dance from a performing arts institute." Amrih Widodo, "The Stages of the State: Arts of the People and Rites of Hegemonization," Review of Indonesian and Malayan Affairs 29,1\&2 (1995): 4.

${ }^{21}$ See Greg Acciaioli, "Culture as Art: From Practice to Spectacle in Indonesia," Canberra Anthropology 8,1\&2 (1985): 159-60; Philip Yampolsky, "Forces for Change in the Regional Performing Arts of Indonesia," Bijdragen tot de Taal-, Land-en Volkenkunde, Performing Arts in Southeast Asia 151,4 (1995): 70025; Widodo, "The Stages of the State," pp. 1-35.

${ }^{22}$ Acciaioli, "Culture as Art," pp. 159-60.

${ }^{23}$ Yampolsky, "Forces for Change," p. 707.

${ }^{24}$ Ibid., p. 710
} 
invitations to perform at festivals and competitions held at district, provincial, or national levels, and to gain exposure on the "tourist circuit." 25

The downfall of Suharto in 1998, and the brief presidency of B. J. Habibie (May 1998-October 1999), marked the beginning of the current Reformasi period. This period introduced 1) a freer system of elections, the formation of more political parties, and the relaxing of the control of the press, 2) a widespread questioning of New Order values and a quest for democracy, and 3) an emphasis on decentralization and regional autonomy. ${ }^{26}$ Structural changes in the government's organization of the arts and development of cultural tourism under President Megawati Sukarnoputri from 2001 allowed government ministries and budgets to realign the arts and culture with tourism rather than education to form Kemparsenibud (Kementerian Pariwisata, Seni dan Kebudayaan; Ministry for Tourism, Arts, and Culture). However, the restructure was short-lived, and culture soon once again linked up with education to form the government ministry Kemendiknas (Kementerian Pendidikan Nasional, Indonesian Ministry of Education) from late 2004 under President Susilo Bambang Yudhoyono. Kemendiknas was subsequently renamed Kemdikbud (Kementerian Pendidikan Budaya, Ministry of Education and Culture), and soon after once again referred to as Depdikbud.

Regional autonomy and structural changes in the central government's organization of the arts and cultural tourism from 1998 onwards resulted in many of the provinces of Indonesia increasingly directing their local activities to rejuvenate the local arts and traditions. This was largely due to the introduction of the new arts policy that gave fairer treatment to the regions. ${ }^{27}$

However, in the Skala Brak region of West Lampung, sakura masked theater charts its own history, punctuated by a series of events that occurred independently of national arts' policies administered centrally and outwardly to the regions. Large-scale transmigrations to Lampung that started in 1908 under Dutch rule continued for more than a century, through the various eras-independence, Guided Democracy, the New Order, Reformasi-and into the present. ${ }^{28}$ This resulted in the significant growth of a non-indigenous majority, which today outnumbers the indigenous Lampung groups, which constitute just 13 percent of the total provincial population (with only 9.3 percent speaking Lampung language). ${ }^{29}$ The remaining 87 percent of the province's inhabitants consist largely of people of Javanese descent (64 percent), with the rest being of Sundanese (9.6 percent), Balinese (1.4 percent) or Bantenese, Chinese, Bugis,

\footnotetext{
${ }^{25}$ Ibid., pp. 711-13.

${ }^{26}$ Margaret Kartomi, "Debates and Impressions of Change and Continuity in Indonesia's Musical Arts since the Fall of Suharto, 1998-2002," Wacana Seni Journal of Arts Discourse 1 (2002): 118.

${ }^{27}$ Ibid., p. 141.

${ }^{25}$ Anton Setyo Nugroho, Miho Fujimura, and Tsukasa Inaoka, "Changes in Socioeconomic Status, Community Health, and Environmental Conditions of Fishermen by Transmigration (transmigrasi) in Lampung Timur, Indonesia," Life Science Journal 9,4 (2012): 790; and Sri Edi Swasono and Masri Singarimbun, Transmigrasi di Indonesia 1905-1985 [Transmigration in Indonesia 1905-1985] (Jakarta: Penerbit Universitas Indonesia, 1985).

${ }^{29}$ Penduduk Indonesia Hasil SP 2010 [Indonesia Population Census 2010] (Jakarta: Badan Pusat Statistik [Indonesian Bureau of Statistics]), available at http: / / www.bps.go.id/, accessed December 3, 2013, pp 200-2, 421-24.
} 
Batak, and Minangkabau descent. (Ninety-five percent of the total population, including the ulun Lampung, are Muslims; 1.5 percent are Hindus; and the rest are Buddhists, Christians, Khong Hu Chus, and others.) For decades, Lampung bupatis and governors, the majority of whom were of non-Lampung descent (typically Javanese migrants appointed by the central government), remained disinterested in developing Lampung identity and Lampung's local arts, and subsequently placed little focus on the ulun Lampung minority. ${ }^{30}$ The national arts' policies administered from Jakarta had regulated the performing arts of Java and other parts of Indonesia. While these policies applied to the arts of the transmigrant (mainly Javanese) majority populations, such as those living in the Lampung town of Metro and other areas in the east and southwest, they did not have an impact on the ulun Lampung and their performing arts' practices to an equal degree. Rather, the ulun Lampung have, for decades, felt undervalued by the immigrant (ethnically diverse) majority (I. kurang dihargai pendatang), whom they believe have accused them of perpetrating violence (I. kekerasan), and of being lazy (I. malas) and arrogant (I. arogan). ${ }^{31}$ This has determined the ulun Lampung's social position as outsiders to mainstream society and has contributed to the undervaluing of their indigenous arts.

In addition, it is important to note that rejuvenation efforts initiated by local leaders in the West Lampung arts had begun several years before the advent of Reformasi. Between 1986 and 1990, the marginalization of the ulun Lampung had become particularly acute when infighting (I. kerusuhan) occurred in Sabatin villages of the Skala Brak region between two rival sakura groups. Male youths wore masks to hide their identities as they committed petty theft and openly carried weapons. ${ }^{32}$ The social disturbance resulting from disenfranchised, unemployed, allegedly volatile males proved to be embarrassing for surrounding communities and the local government. Village elders condoned neither their crimes nor the shame they brought to the community. They, along with local government security forces, regarded the alleged rebellious behavior of the males involved as socially unacceptable, ${ }^{33}$ and called for a reestablishment of social order and traditional values. ${ }^{34}$ Sakura events were banned for four years from 1986 while leaders and local communities were encouraged to

\footnotetext{
${ }^{30}$ The only other ulun Lampung governor besides the current governor, Dr. Hi. (Haji) Sjachroeddin Z.P. S.H., to govern the province since its establishment was Hi. Zainal Abidin Pagar Alam (1966-72). All others were Javanese: Koseno Danu Upoyo (1964-66), R. Sutiyoso (1972-78), Yasir Hadibroto (1978-88), Poedjono Pranyoto (1988-98), and Drs. Oemarsono (1998-2002). See Lampung Dalam Angka 2013: Lampung in Figures (Lampung: Badan Pusat Statistik Provinsi Lampung), available at http:/ / lampung.bps.go.id/ publikasi/ buku/lda2013/files/ assets/ basic-html/ page51.html, accessed January 31, 2014, p. 51.

${ }^{31}$ R. Sinaga, “Revitalisasi Tradisi: Strategi Mengubah Stigma Kajian Pi'il Pesenggiri Dalam Budaya Lampung" [The Revitalization of Tradition: Strategy to Change Social Stigma in the Study of Self-Respect in Lampung Culture] (PhD dissertation, University of Indonesia, 2012), p. vii.

${ }^{32}$ At the popular sakura masked pole-climbing event (sakura cakak buah), adolescents show their sense of humor by making jokes (senda gurau) and shouting out aloud. They feel free to act out behaviors, such as their "kenakalan" (mischievousness), not normally expressed openly in public (Mustika, "Perkembangan Bentuk Pertunjukan," pp. 210-14, 388, 391).

${ }^{33}$ Ibid., p. 391

${ }^{34}$ Both saibatin and pepadun ethnic groups regard specific pi'il pesenggiri social values highly, in particular they value acts that show respectability, such as being hospitable towards guests (including immigrants and visitors from outside Lampung), maintaining dignity, and avoiding displays of violence, laziness, and arrogance. Sinaga, "Revitalisasi Tradisi," p. 132.
} 
collaborate and find ways of controlling such anti-social behavior. ${ }^{35}$ From the early 1990s onwards, sakura events resumed once again, taking place at Idul Fitri and Independence Day celebrations, this time with the support of the local bupati and the new Head of Culture Mulyawan, who, as mentioned, was hired by West Lampung's Department of Tourism, Art, and Culture to revitalize the Saibatin arts. Select youths (kaum muda) were additionally instructed to go undercover at these events wearing black cloth masks and to work together with security police and local officials to control any further outbreaks of crime, violence, and other anti-social acts between sakura groups. ${ }^{36}$

While the resignation of Suharto and the advent of Reformasi did not directly affect the ulun Lampung arts, it did seriously affect Lampung's power structure. With the eventual election of the Lampung-born governor in 2004, Bp. Sjachroedin $\mathrm{ZP}$, the marginalization of the Lampung minority came into full view and became a major challenge facing his government. The formation of the Council of Elders for Lampung Traditions (MPAL, Majelis Penyimbang Adat Lampung) enabled the systematic implementation of a province-wide cultural program to address the long-term neglect of Lampung arts and culture. ${ }^{37}$ Efforts to revive the arts and traditions of the ulun Lampung were no longer restricted to West Lampung but spanned across all the regencies of Lampung. MPAL began to implement a long-term plan that encouraged local ethnic communities to revitalize their indigenous arts. MPAL's charter was to assist local bupatis and their respective governments to engage in activities designed to preserve (I. melestarikan) the local arts, ${ }^{38}$ and also to advise on and assist in the funding and the staging of local performance groups at government events and functions. ${ }^{39} \mathrm{~A}$ significant, stated aim of the current governor has been to "... menjaga kelestarian budaya, menghargai budaya provinsi ini, dan menyadarkan bahwa inilah Lampung" ([I.] ... take measures to sustain the culture, value the province's culture, and raise awareness that this is Lampung). ${ }^{40}$ At the core of his challenge lies the intention to "... membangkitkan kesadaran kolektivisme ulun Lampung" ([I.] to raise the collective consciousness of the indigenous Lampung people), to uphold the value of pi'il

\footnotetext{
"Mustika, "Perkembangan Bentuk Pertunjukan," p. 220. Using masks to control behavior is not new in Lampung. Legend has it that sakura masks may have been worn by secret guards of three Lampung heroes (I. tokoh kesatria) from the eighteenth and nineteenth centuries: Radin Inten I (1751-1828), Radin Imba II (1828-34), and Radin Inten II (1834-56). They dressed their armies of freedom fighters in wooden masks and clothes of banana leaves to camouflage themselves during battles against Dutch troops. See N. Anggraeny, "Tari Tupping Pesisekh" [Masked Dance of the Coast] (MA thesis, Institut Seni Indonesia Yogyakarta, 2012). Later, in 2002, members of the studio Sanggar Stiwang from Liwa, who performed vocal music in sakura helau costume at the first sakura performance held outside of West Lampung, were trained civil service police (from the Polisi Pamong Praja [Regional Civil Service Police Unit]). The sakura seribu wajah event held during the fifteen-day-long Krakatau Festival was part of a covert security taskforce to maintain public order at the Saburai Sports Venue and Stadium in the capital city of Bandar Lampung. See Mustika, "Perkembangan Bentuk Pertunukan," p. 13.

${ }^{36}$ Ibid., p. 220.

${ }^{3}$ HI Kadarsyah Irsa SE (Provincial General Chairman of MPAL), Zafrullah Khan SH, and HI Nasrun Rakai SH., personal communication, April 2012, Bandar Lampung.

${ }^{38}$ Hesma Eryani, Inspirator Tanpa Kultus: Biografi Sjachroedin Zainal Pagar Alam (Bandar Lampung, Sumatra: CV Matakata Media, 2012), pp. 136-39.

${ }^{39}$ HI Kadarsyah Irsa SE (Provincial General Chairman of MPAL), Zafrullah Khan SH, and HI Nasrun Rakai SH, personal communication, April 2012, Bandar Lampung.

${ }^{40}$ Hesma Eryani, Inspirator Tanpa Kultus, p. 136.
} 
pesenggiri (self-respect), and to articulate an ulun Lampung identity (I. jati diri). Cultivating cultural pride in the indigenous arts is seen as an effective way of addressing the social stigma experienced at the hands of Lampung's diverse immigrant majority. ${ }^{41}$ Only from 2008 onwards, several years after the Lampung arts and culture revitalization program came into being, were sakura groups granted regular opportunities to perform at official local and provincial government functions and festivals, including the large-scale festivals in the capital city of Bandar Lampung and in Kotaagung city in Tanggamus regency, South-Central Lampung. ${ }^{42}$

The internal political drive to rejuvenate the traditional arts across Lampung (many of which were also regularly performed at transition ceremonies such as weddings, the conferring of traditional titles, circumcisions, tooth-filings, and funerals) was brought home to me in 2011 and 2012 when I attended six local government functions in four different kabupaten. Two were held in Lampung's capital, Bandar Lampung, another in the northwest (in Belambangan Umpu, Kabupaten Way Kanan), one was held in central Lampung (in Tanggamus, Kabupaten Lampung Tengah), and a day and an evening function were held in the east (in Sukadana, Kabupaten Lampung Timur). ${ }^{43}$ The bupatis' official speeches consistently emphasized the need to preserve, revitalize, and reinstate (I. membangkitkan) local artistic traditions. Their elaborate ceremonies were structured around the process of Lampung traditions (I. proses adat Lampung) of music and dance, including atraksi silat [I. martial arts attractions] and tarian khas Lampung [I. dances unique to Lampung], which were often additionally performed in procession. Participants and performers used appropriate items of traditional regalia, such as the gold, boat-shaped siger (Lampung-style headdress) and traditional costume, and, in one case, the traditional chariot (rata). More often than not, talo balak ensembles accompanied these performances of traditional and contemporary dance. Such speeches embellished by lavish theatrical ceremonies of traditional music and dance illustrate the ambitions of Lampung bupatis to support and influence the revival efforts in the arts in the current era.

\footnotetext{
${ }^{41}$ Sinaga, "Revitalisasi Tradisi," p. vii; Sulistyowati Irianto and Risma Margaretha, "Pi'il Pesenggiri: Modal Budaya dan Strategi Identitas Ulun Lampung" [Self Respect: Cultural Capital and Strategy for the Identity of Lampung People] Makara, Seri Sosial Humaniora [Makara of Social Sciences and Humanities Series] 15,2 (2011): 145.

${ }^{42}$ In 2008, sakura groups also performed in Jakarta at Taman Mini Indonesia Indah (TMII, the national cultural miniature theme park), at the Taman Budaya Yogyakarta (Cultural Park Yogyakarta), and at the Institut Keguruan dan Ilmu Pendidikan (IKTP, the Institute of Teacher Training and Education) in Yogjakarta. See further "HUT ke-20 Kabupaten Lampung, Ribuan Warga Hadiri 1001 Topeng Sekura" IThe Twentieth Birthday of the Lampung Regency, Thousands Attend the One Thousand and One Sekura Masked Event], Rimanews, September 18, 2011, available at http: / / www.rimanews.com/read/20110918/ 41326/ hut-ke-20-kabupaten-lampung-ribuan-warga-hadiri-1001-topeng-sekura, accessed December 20, 2013.

${ }^{43}$ The first of the six speeches took place in December 2011 and was given by the governor of Lampung, Dr. Hi. (Haji) Sjachroeddin Z.P. S.H.,, at an adok (title-conferring) ceremony in Banda Lampung. The remaining five speeches took place in April 2012 and were given by: the mayor of Bandar Lampung, Drs. Hi. Herman H.N. M.M., at a gathering for the city's civil servants, also in Bandar Lampung; the bupati of Way Kanan, Hi. Bustami Zainudin S. P.D., at a title-conferring ceremony in Belambangan Umpu; the bupati of Tanggamus, Bp. Hi. Bambang Kurniawan S.T., in Kotaagung; and Bp. Erwin Arifin S.H., M.H., the bupati of East Lampung regency in Sukadana, first at an afternoon official function, and then again in the evening at a large-scale cultural event for the community to celebrate the thirteenth anniversary of the formation of the regency.
} 
The official intervention in the Skala Brak arts led by artistic director and Head of Culture Mulyawan, and instigated by the regency's bupati, has clearly brought significant change to the traditional indigenous performing arts of West Lampung. ${ }^{44}$ The new sakura helau dance is now performed alongside the traditional sakura kamak processional theater. A shortened version of the masked dance is deemed suitable for presentation to audiences of officials at provincial and national functions and festivals, Independence Day and Idul Fitri celebrations, and for audiences of foreign and domestic tourists and visitors to Indonesia. If performed at large-scale government events, sakura's ties to its traditional function of bersih desa, and evocations of the world of ancestral spirits, are downplayed or not acknowledged. Male sakura maskers do not don the old, wooden masks, but, rather, wear newly made and brightly painted masks, or they swathe their heads and faces in Lampung contemporary batik cloth. No longer do they dress in rags, kain (I. cloth worn as a short or long sarong), and leafy branches, but, instead, costume their bodies with the Malay teluk belanga trouser suit, sarong, a tightly tied scarf across the chest, and the silver or gold-threaded tapis ${ }^{45}$ sarong, and accessorize with mock swords. Sakura in its contemporary helau form consists not of free-style movements typical of the traditional kamak form, but of kreasi dance routines with stylized silat, kesatria-type movements and stances that are performed by groups of eight or twelve male dancers in uniform or choreographed formation. Indeed, some of the standing and moving postures of the sakura helau dance, to my mind, resemble the Javanese lumaksana (J. walking) stance and stylistic walk, with the right leg stretching forward diagonally and the toes curling up, combined with the bapang kasatriyan (J. prince movement ${ }^{46}$ ) with the right arm held at shoulder level and the left arm held up to the left side of the head. ${ }^{47}$ Other stances parallel those of the Balinese agem, an asymmetrical stance in which the body weight rests on the right foot with the left foot in a modified third position. ${ }^{48}$

\footnotetext{
${ }^{44}$ Other kreasi versions based on traditional Saibatin dances choreographed by Mulyawan include the muli sembah-or the sembah batin dance, accompanied by a kelenongan (framed gongs), with a row of six kettle gongs and a second kelenongan with a row of five kettle gongs, a talo balak (large gong), and a talo lunik (smaller gong) suspended from a wooden frame. In addition, Mulyawan choregraphed a version of the traditional cangget (long-fingernail) dance, which is accompanied by a talo balak ensemble. Both these dances were also performed at the Canggu sakura festival described in this article.

${ }^{45}$ Tapis is traditional Lampung cloth woven with gold or silver thread and worn and used at ceremonies as ceremonial artifacts. See Mary-Louise Totton, Wearing Wealth and Styling Identity: Tapis from Lampung, South Sumatra, Indonesia (Hanover, NH: Hood Museum of Art, Dartmouth College, 2009).

${ }^{46}$ In Surakata Javanese dance, bapang movements indicate a strong male character who uses asymmetrical and contrasting arm lines. The bapang kasatriyan style is often performed by strong demonic characters. See R. M. Soedarsono, "The Impact of Tourism on Indonesian Performing Arts," Tourism and Education 3, (2003); available at http: / / urp.fib.ugm.ac.id/ post/detilKontributor?id=10, accessed January 31, 2014, pp. $81-84$, fns. 7, 15, and 18. In Balinese dance, bapang refers to a cycle or type of movement, usually with 8beat meters or melodies. See Michael Tenzer, "The Social Construction of Kebyar Ensemble Virtuosity," Chapter 3, Gamelan Gong Kebyar: The Art of Twentieth-Century Balinese Music (Chicago, IL: University of Chicago Press, 2000), pp. 89, fn 14; and 191.

${ }^{47}$ Clara Brakel-Papenhuyzen, Classical Javanese Dance: The Surakarta Tradition and Its Terminology (Leiden KITLV Press, 1995), p. 109

${ }^{48}$ Compare Wayan Dibia and Rucina Ballinger, Balinese Dance, Drama, and Music: A Guide to the Performing Arts of Bali (Singapore: Periplus, 2004), p. 18. Some of the stylistic movements and stances of the Sundanese Kelana masked dance that I studied in Jakarta in 1984 equally resonate with the dance movements of sakura helau.
} 
Despite the fact that official intervention has brought significant change to the traditional indigenous arts, kreasi Saibatin dances such as those choreographed by Mulyawan are widely accepted among the communities of Lampung. ${ }^{49}$ Contrary to Indonesia's other regional arts, the management of which was largely regulated by Depdikbud during the New Order and then handed over to regional governments in the Reformasi period, sakura helau and other contemporary Saibatin dances are regarded not only as embodying but also contemporizing elements of traditional culture. Without official intervention initially from local government in the early 1990s, then from the provincial government in the mid- to late 2000s, sakura's position would not enjoy its current elevated status of an officially endorsed art form. ${ }^{50}$ It would not have gained broad recognition, nor would it have assisted in regenerating a Saibatin cultural (and artistic) identity (I. jati diri masyarakat beradat Saibatin) to the same extent. ${ }^{51}$

The Skala Brak sakura festival enjoyed annually at Idul Fitri constitutes the biggest performance of the year and involves the whole community. Organizers and participants are busy well before the event, preparing, recruiting participants, and securing an outdoor street venue. Thus, the traditional Lampung injunction to work together (beguai jejama) is implemented with dignity, thereby increasing the pride of participants and audience in their indigenous heritage and pi'il pesenggiri. At the same time as it aims to reclaim and legitimize the salient cultural markers of the ulun Lampung, sakura masked theater proudly brings these elements alive in theatrical processional, musical, and dance forms. ${ }^{52}$ The local official push to revive and transform the indigenous performing arts suitable for government functions is done so with the collective support of local communities, and with the intention of restoring and validating the dignity of the ulun Lampung.

\section{Conclusion}

Conversations with performers, artists, and members of the community whom I met in West Lampung confirmed that the local performing arts' community is encouraged to preserve the indigenous ceremonial traditions. They spoke with pride about their traditional and contemporary art forms that aim to reestablish and reassert a cultural and artistic identity. Sakura masking evokes a glorious past with ancient spiritual connections that preserves a lasting affiliation with the people's pre-Muslim roots. The contemporary masked sakura helau form is regarded as a legitimate source of cultural pride, an art form whose roots lie with the sakura kamak ritual practiced by the original Buay Tumi ancestors on and around Mount Pesagi.

\footnotetext{
${ }^{49}$ Mustika, "Perkembangan Bentuk Pertunjukan," p. 232.

${ }^{50}$ This differs from Yampolsky's definition of "official art," which refers to those art forms 1) that have been "disinfected" or "upgraded" by forces of change, 2) that are "... parallel to but divorced from the true artistic life of Indonesians," and 3) where the effects of upgrading are felt only in official contexts. See "Forces for Change," p. 719.

${ }^{51}$ Ibid., pp. 158-59, 209. The sakura helau dance is not seen by performers as being stylistically Balinese due to the choreographer's cultural background. Instead, it is seen as representing contemporary Saibatin masked dance, as noted (performers from Sanggar Seni Setiawan, personal communication, A pril 2012, Kenali, Lampung).

${ }^{52}$ Performers from Sanggar Seni Setiawan, personal commiunication, April 2012, Kenali, Lampung.
} 
The history of Lampung's indigenous performing arts in the last one hundred years, and particularly in the last twenty years, has shown its own course of development. Depdikbud policies coming out of Jakarta focused mainly on regulating the arts of the majority in the regions, and had little impact on the performing arts of the ulun Lampung minority. In the early 1990s, several years before the advent of Reformasi in 1998, local government officials supported Mulyawan in his efforts to resuscitate the Saibatin culture and traditions in the region. This initiative was done in a way that was unlike such efforts in population centers dotted around the province and populated by large transmigrant Javanese (and other immigrant) communities, inasmuch as Mulyawan's efforts were locally sponsored and focused on the indigenous minority's traditional arts. As a government official straddling the artistic, community, and official worlds for the past two decades, Mulyawan gained full support from the local artistic and broader community.

While the changeover from the central New Order regime to Reformasi in 1998 barely had an impact on Lampung's indigenous performing arts, it did, however, seriously alter Lampung's power structure. With the appointment of an ulun Lampung governor in 2004, the focus shifted to "all things Lampung." This resulted in the implementation of an arts policy that centered around Lampung's pi'il pesenggiri philosophy. Official intervention in the Skala Brak arts, which developed with both the clear support of individual bupatis, district leaders, and their respective governments, and, later, the strong backing of the MPAL and the current governor, has no doubt brought significant change to the traditional indigenous performing arts of West Lampung. Mulyawan's already high artistic standing among the community and his diplomatic manner as go-between within the structure of officials, artists, and the community provided the passage for smooth, unproblematic artistic development and broad public acceptance of his creative leadership and choreography. Each sakura festival is an enactment of ulun Lampung identity. The activities surrounding the revival of the performing arts has helped regenerate and legitimize the cultural identity of the Saibatin ethnic minority, which every live sakura performance reenacts. 